\title{
Phytochemical and anti-microbial analysis of the roots of ficus exasparata (anwirinwa)
}

\author{
Onyema, Chukwuebuka ThankGod"; Ajiwe, Vincent Ishmael; Nwankwo, Ogochukwu Obioma
}

Pure and Industrial Chemistry Department, Faculty of Physical Sciences, Nnamdi Azikiwe University, Awka, Anambra State, Nigeria

\section{Email address:}

ct.onyema@yahoo.com, ct.onyema@unizik.edu.ng (Onyema C.T)

\section{To cite this article:}

Onyema, Chukwuebuka ThankGod; Ajiwe, Vincent Ishmael; Nwankwo, Ogochukwu Obioma. Phytochemical and Anti-Microbial Analysis of the Roots of Ficus Exasparata (Anwirinwa). Science Journal of Chemistry. Vol. 2, No. 3, 2014, pp. 11-16.

doi: $10.11648 /$ j.sjc.20140203.11

\begin{abstract}
The roots of Ficus exasparata of the Moraceae family were duly analysed to ascertain the active constituents responsible for the use of the plant part in the treatment of inflammatory diseases, treatment of internal bleeding, bruises, cough and dangerous boils among others. The phytochemical analysis showed the presence of some secondary metabolites in various concentrations with saponin and alkaloids present in low concentration while reducing sugars were present in very high concentration with protein, carbohydrates and acidic components totally absent. The Atomic Absorption Spectroscopic (AAS) analysis showed the presence of certain trace elements such as $\mathrm{Cd}(0.55 \mathrm{ppm}), \mathrm{Cr}(1.88 \mathrm{ppm}), \mathrm{As}$ $(0.38 \mathrm{ppm}), \mathrm{Hg}(0.09 \mathrm{ppm})$ etc which were higher than the WHO recommended standard of $\mathrm{Cd}(0.003 \mathrm{ppm}), \mathrm{Cr}(0.05 \mathrm{ppm})$, As $(0.01 \mathrm{ppm}), \mathrm{Hg}(0.001 \mathrm{ppm})$ respectively an observation that could be attributed to the crude nature of the plant parts. Three different choice solvents (Chloroform, Ethylacetate and Chloroform-Methanol mixture) were used in the extraction of the plant part. The extracts were subsequently subjected to thin layer chromatography with respective Rf values as 0.13 , 0.22 and 0.60 respectively showing just a single spot each for all the solvents used. The extracts were subjected to antimicrobial screening using eight pathogenic bacteria species and three fungi with only the chloroform extract exhibiting activity on the selected test organisms. The three extracts from the sample were subjected to structural elucidation using a combination of some spectroscopic techniques such as FTIR, UV-VIS, $\mathrm{H}^{1}$-NMR, $\mathrm{C}^{13}$-NMR and GCMS. The spectral analysis suggested the presence of Coumarin-3-carboxamide, 8-allyl-N-(3-nitrophenyl) and 1,2,3-propanetricarboxylic acid, 2-(acetyloxy)-tributyl ester for chloroform and ethyl acetate extracts respectively. The constituents of these extracts such as Coumarin in chloroform extract could account for its potency in curing certain illnesses as coumarin is a well known natural product that has displayed a broad range of biological activities.
\end{abstract}

Keywords: Ficus Exasparata, Phytochemical Analysis, Anti-Microbial Analysis, Structural Elucidation, Spectroscopic Technique

\section{Introduction}

In Africa, the use of traditional medicine dates back to the beginning of mankind as man in his quest to achieve good and healthy living examined all aspects of his environments by trial and error [1,2]. Ancient man also discovered some medicinal plants and their curative activities by closely monitoring the effect a specific plant will have on a sick animal after eating a particular plant or its parts. A goat with runny stomach which got healed after eating guava leaves could account for the use of guava leaves in tackling such cases in man today.

Every community in Nigeria has peculiar herbs and plants which are used in some ways for the treatment of symptoms and diseases varying from skin rash to cancers $[3,4]$. Therefore, each plant or herb for example Ficus exasparata a pale greenish tree native to Sub-Saharan African should be thoroughly studied in terms of its biochemical contents and medical effects in other to examine their overall safety for therapeutic usage. Ficus exasparata roots have been documented to have measurable effects on mean blood pressure when administered to rabbits, anti-diabetic, lipid lowering and anti-fungal activities $[5,6]$ 


\section{Experimental}

\subsection{Plant Collection, Identification and Preparation}

The roots of Ficus exasparata were collected from Nawfia in Njikoka Local Government Area of Anambra State in Eastern Nigeria. It was subsequently identified by a taxonomist, Dr Mbaekwe of the Botany Department of Nnamdi Azikiwe University, Awka, Anambra State Nigeria through its leaves. The samples were washed under running water and dried at room temperature to avoid heat destruction of the active components. The dried samples were ground into fine particles using a mechanical grinder and kept in an air tight container for further use.

\subsection{Extraction and Fractionation into Different Classes}

$500 \mathrm{~g}$ of the pulverized root sample was homogenized for 1hour 30 minutes in $2500 \mathrm{ml}$ of methanol/water in a ratio of $4: 1$. The mixture was filtered and concentrated to one-tenth of its volume on a water bath maintained at $40^{\circ} \mathrm{C}$. The filterate was then acidified with $2 \mathrm{M} \mathrm{H}_{2} \mathrm{SO}_{4}$ and then extracted trice with chloroform resulting in two layers; the chloroform layer and the aqueous acid layer. These were separated using a separatory funnel to give the chloroform extract leaving behind the aqueous acid layer [7].

The aqueous acid layer was basified with ammonium hydroxide to $\mathrm{pH} 10$ and extracted twice with chloroformmethanol mixture in 3:1 ratio to give the chloroformmethanol mixture. The aqueous basic layer was heated to near dryness and precipitated with methanol to give white crystals which was filtered and washed severely with methanol. This crystal is suspected to be of quarternary alkaloids and could be confirmed through the structural elucidation. The residue obtained after maceration of the sample in the mixture of methanol-water were soaked in $100 \mathrm{ml}$ of ethyl acetate for about $30-45 \mathrm{~min}$ and then filtered to give the ethyl acetate extract [7].

The various fractions were subsequently subjected to preparative thin layer chromatography in order to possibly separate them into other fractions.

\subsection{Phytochemical Screening}

The crude root extract was evaluated for the presence of Acidic compounds, flavonoids, saponin, resins, proteins, oils, steroids, tannins, alkaloids, reducing sugar, carbohydrates and cardiac glycosides using standard procedures [7]

\subsection{Trace Metal Examination}

Trace metals content ( $\mathrm{Zn}, \mathrm{Fe}, \mathrm{Cd}, \mathrm{Na}, \mathrm{Cr}, \mathrm{As}, \mathrm{Pb}, \mathrm{Hg}$ and Co) of the crude root extract was determined using Atomic Absorption Spectrophotometer (varian AA 280). Its value was compared against the WHO accepted limits.

\subsection{Anti-Microbial Assay}

The sensitivity of the various root extracts against selected test organisms (Bacillu substilis, Klebsiella aerogenes, Streptococcus species, Proteus Vulgaris, Enterobacter aerogenes, Pseudomonas aerogenes, Aspergillus niger, Aspergillus flavus, Candida albican) was carried out using the Punched agar diffusion method while the serial dilution method was used for the determination of $\mathrm{MIC}$ and $\mathrm{MBC}$.

\subsection{Structural Elucidation}

Using a combination of some spectroscopic techniques such as FTIR, UV-VISIBLE, GCMS, $\mathrm{H}^{1}$-NMR, and $\mathrm{C}^{13}$ $\mathrm{NMR}$, structures and molecular formulae of the various pure extracts of the roots of Ficus exasparata were proposed.

\section{Results and Discussion}

The results of the organoleptic examination of the root are as given in Table 1.

Table 1. Organoleptic Examination of the Roots of Ficus exasparata

\begin{tabular}{lll}
\hline Colour & Texture & Taste \\
\hline Green & Rough & Bitter \\
\hline
\end{tabular}

The bitter taste pointed to the possibility of the presence of tannin as confirmed by the phytochemical screening result.

Table 2. Phytochemical Composition of the roots of Ficus exasparata

\begin{tabular}{|c|c|c|c|c|}
\hline Alkal & Alkaloids & Cardiac & Flavonoids & Sapor \\
\hline Components & & \multicolumn{3}{|c|}{ Glycosides } \\
\hline+ & + & ++ & ++ & + \\
\hline \multicolumn{5}{|c|}{ Note: - Absent, + Present in low Concentration, ++ Present in high Concentra } \\
\hline \multicolumn{5}{|c|}{$\begin{array}{l}\text { Table 3. Result of Thin Layer Chromatography (TLC) of crude extract of } \\
\text { the Ficus exasparata }\end{array}$} \\
\hline Extract & $\mathbf{R}_{\mathrm{f}}$ Value & Solv & ems & \\
\hline Chloroform & 0.13 & $\begin{array}{l}\text { Chlo } \\
(90:-\end{array}$ & thylacetate & \\
\hline Ethyl acetate & 0.22 & $\begin{array}{l}\text { Chlor } \\
(90: 4\end{array}$ & ethylacetate: & \\
\hline Chloroform/Methanol & 0.66 & $\begin{array}{l}\text { Pet. } \\
(80: 2\end{array}$ & lacial Acetic & \\
\hline
\end{tabular}

The phytochemical result of the roots of Ficus exasparata showed the presence of alkaloids, cardiac glycosides, flavonoids, saponin, tannins, reducing sugar, resins, oils in various concentrations with acidic component conspicuously absent. The absence of any acidic component showed the non-toxic nature of the plant parts while the presence of some other phytochemicals showed the potency of this plant part for theraupeutic uses. The 
high presence of flavonoids helps to reinforce capillary walls, improving exchange of nutrient and oxygen between the blood and tissues [7]. The presence of tannin in the leaves confirmed the bitter taste recorded in the organoleptic test (Table 1) which also showed the antibacterial properties of the plant part and the possible usage of it in toning of vital organs such as liver, kidney etc $[6,8,9,10,11]$
The thin layer result of the plant extract using various solvent media showed single spots under iodine vapour with respective Rf values as given in Table 3. This showed that the plant part contained a single isolable phytochemical in the various solvents used for the extraction.

Table 4. Results of the Mineral Elements Found in the Roots of Ficus exasparata

\begin{tabular}{llllllllll}
\hline Element & As & Cd & Cr & Co & Fe & Pb & Hg & Na & Zn \\
\hline Roots (mg/g) & 0.38 & 0.55 & 1.85 & 2.09 & 1.90 & 0.34 & 0.09 & 5.10 & 0.38 \\
WHO & 0.01 & 0.003 & 0.005 & 0.01 & & & 0.001 & & \\
Standard & & & & & & & & & \\
\hline
\end{tabular}

The heavy metal level of this plant was above the WHO permissible levels this could be attributed to its crude nature hence showing the need for further purification to avert the adverse effects of these heavy metals as a result of their gradual accumulation in the body. However, few other essential elements like $\mathrm{Zn}, \mathrm{Fe}$ and Na most especially where found in substantial amount.

Table 5. Results of Antimicrobial Activity of Extracts/Fractions of the Roots of Ficus exasparata

\begin{tabular}{lllllllllllll}
\hline Extracts & Vol.Used $\left(\mathbf{c m}^{3}\right)$ & \multicolumn{4}{l}{ Average Diameter $(\mathbf{m m})$ Zones of Inhibition on Test Organisms } & & \\
\hline & & E.Coli & S.Au & E.A & P.V & STRPT & B.S & P.A & K.A \\
& & (NCTC 10481) & L.C.I & L.C.I & L.C.I & L.C.I & L.C.I & L.C.I & L.C.I \\
Chloroform & 0.05 & 28 & 36 & 38 & 30 & 20 & 18 & 14 & 16 & NA \\
Ethylacetate & 0.05 & NA & NA & NA & NA & NA & NA & NA & NA \\
$\mathrm{CHCl}_{3} / \mathrm{MeOH}$ & 0.05 & NA & NA & NA & NA & NA & NA & NA & NA \\
\hline
\end{tabular}

E.Coli $=$ Escherichia Coli, S.Au= Staphylococcus aureus, E.A=Enterobacter aerogenes, P.V=Proteus vulgaris, STRPT= Streptococcus specie, B.T=Bacillus typhi, $\mathrm{P} . \mathrm{A}=$ Pseudomonas aeroginosa, $\mathrm{K} . \mathrm{P}=$ Klebsiella pneumonia .

Only the chloroform extract of the roots of Ficus exasparata showed positive effect on the selected test organisms showing that the other solvents (Ethyl acetate and Chloroform/Methanol) could contain compounds that had no contribution to the antimicrobial action of this plant.

Table 6. Results of Minimum Inhibitory Concentration (MIC) and Minimum Bactericidal Concentration (MBC) of the roots of Ficus exasparata

\begin{tabular}{|c|c|c|c|c|c|c|c|c|c|}
\hline \multirow[t]{2}{*}{ Extracts } & & \multicolumn{8}{|c|}{ Average Diameter (mm) Zones of Inhibition on Test Organisms } \\
\hline & & E.Coli & S.Au & E.A & P.V & STRPT & B.S & P.A & K.A \\
\hline \multirow{3}{*}{ Chloroform } & & (NCTC 10481) & L.C.I & L.C.I & L.C.I & L.C.I & L.C.I & L.C.I & L.C.I \\
\hline & MIC & 0.0156 & 0.0156 & 0.0156 & 0.0156 & 0.0025 & 0.125 & 0.25 & 0.125 \\
\hline & $\mathrm{MBC}$ & 0.0312 & 0.0312 & 0.0312 & 0.0312 & 0.125 & 0.250 & 0.50 & 0 \\
\hline
\end{tabular}

E.Coli = Escherichia Coli, S.Au= Staphylococcus aureus, E.A=Enterobacter aerogenes, P.V=Proteus vulgaris, STRPT= Streptococcus specie, B.T=Bacillus typhi, P.A=Pseudomonas aeroginosa, K.P = Klebsiella pneumonia.

The results of the antibacterial activity on eight pathogenic bacteria species both gram positive bacteria and gram negative bacteria showed that the chloroform root extract could serve as a broad spectrum anti microbial [12]. The high presence of flavonoids in the root from the phytochemical tests could have accounted for the anti microbial effect as one of the major roles of flavonoids and related polyphenol is protection against microbial invasion $[13,14]$.
Table 7. Results of the MIC and MFC of the Roots of Ficus exasparata

\begin{tabular}{lllll}
\hline \multirow{3}{*}{ Extracts } & & \multicolumn{2}{l}{$\begin{array}{l}\text { Presence or } \\
\text { Organisms }\end{array}$} \\
\cline { 3 - 5 } & & $\begin{array}{l}\text { Candida } \\
\text { Albican }\end{array}$ & $\begin{array}{l}\text { Aspergillus } \\
\text { flavus }\end{array}$ & $\begin{array}{l}\text { Aspergillus } \\
\text { Niger }\end{array}$ \\
\cline { 3 - 5 } & & L.C.I & L.C.I & L.C.I \\
\hline Chloroform & MIC & 0.250 & 0.125 & 0.0312 \\
& MFC & 0.500 & 0.250 & 0.0625 \\
\hline
\end{tabular}


The results of the antifungal activity on three strains of pathogenic fungi showed the chloroform root extract of the plant had remarkable effect on the test organisms given by their MIC and MBC as such could be used in the treatment of diseases caused by these organisms.

\subsection{Spectroscopic Analysis and Structural Elucidation}

Table 8. FTIR Results of Chloroform root extract

\begin{tabular}{ll}
\hline Wave band $\left(\mathbf{c m}^{-1}\right)$ & Description \\
\hline 2929.97 & $\begin{array}{l}\text { N-H Stretch for amines, C-H Stretch for alkane, } \\
\text { alkyl group }\end{array}$ \\
1266.31 & C-H deformation, C=O Stretch \\
744.55 & C-H deformation bonds for aromatics and alkyl \\
452.32 & groups \\
\hline
\end{tabular}

Table 9. UV-Visible Results of Chloroform root extract

\begin{tabular}{ccc}
\hline $\boldsymbol{\lambda} \max (\mathbf{n m})$ & Chromophore & Description \\
\hline 667.00 & $\mathrm{O}=\mathrm{C}=\mathrm{N}-\mathrm{H}$ & $\left(\mathrm{n} \longrightarrow \pi^{*}\right)$ attached to aromatic bonds showing high conjugation \\
606.50 & $-\mathrm{C}=\mathrm{O}$ & \\
493.50 & $-\mathrm{C}=\mathrm{C}-$ & $\left(\mathrm{n} \longrightarrow \pi^{*}\right)$ attached to aromatic bonds showing high conjugation \\
\hline
\end{tabular}

Table 10. Summary of the $H^{l}$ and $C^{13} N M R$ Results of Chloroform root extract

\begin{tabular}{|c|c|c|c|c|}
\hline $\mathbf{H}^{1} \delta(\mathrm{ppm}) \&$ Multiplicity & Coupling Constant (MHz) & Types of Proton & $\mathrm{C}^{13} \delta(\mathrm{ppm})$ & Types of Carbon \\
\hline $0.8(\mathrm{t})$ & 23.70 & ArH & 77.677 & $\mathrm{C}=\mathrm{O}$ \\
\hline $1.2(\mathrm{~d})$ & 45.12 & $\mathrm{RNH}$ & 77.033 & $\mathrm{C}=\mathrm{O}$ \\
\hline $1.6(\mathrm{~d})$ & 13.95 & ArH & 76.403 & $\mathrm{C}-\mathrm{O}$ \\
\hline $2.3(d)$ & 13.46 & $\mathrm{ArH}$ & 65.099 & $\mathrm{C}-\mathrm{NO}_{2}$ \\
\hline 3.9 (d) & 1.41 & ArH & 49.754 & CNAr \\
\hline \multirow[t]{14}{*}{$4.1(\mathrm{~d})$} & 2.37 & $\mathrm{CH}$ & 45.785 & C-atom \\
\hline & & & 34.159 & C-atom \\
\hline & & & 31.904 & C-atom \\
\hline & & & 31.406 & CAr \\
\hline & & & 29.679 & CAr \\
\hline & & & 29.444 & $\mathrm{CAr}$ \\
\hline & & & 29.342 & CAr \\
\hline & & & 29.239 & CAr \\
\hline & & & 29.108 & $\mathrm{CAr}$ \\
\hline & & & 27.292 & CAr \\
\hline & & & 24.890 & CAr \\
\hline & & & 22.679 & $\mathrm{CH}$ \\
\hline & & & 18.990 & $\mathrm{CH}_{2}$ \\
\hline & & & 14.099 & $\mathrm{CH}_{2}$ \\
\hline
\end{tabular}

The combination of the FTIR, UV-VIS, $\mathrm{H}^{1}-\mathrm{NMR}, \mathrm{C}^{13}$ NMR results with major fragments in the GCMS gave rise to the proposed structure for the compound of chloroform extract (fig 1.0)

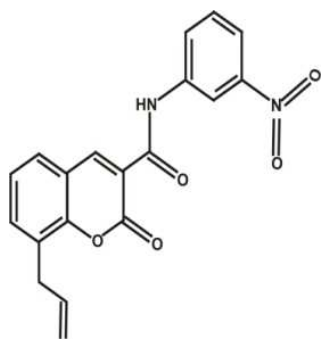

Fig 1.0. Coumarin-3-carboxamide, 8-allyl-N-(3-nitrophenyl) $\left(\mathrm{C}_{19} \mathrm{H}_{14} \mathrm{~N}_{2} \mathrm{O}_{5}\right)$
Coumarins a part of the above compound are nowadays an important group of organic compounds and are well known natural products displaying a broad range of biological activities [15]. Coumarin derivatives have also been used as therapeutic agents, optical bleaching agent [16]. These amongst others could account for the antimicrobial effect of the extract and also confirm this as the possible structure of the active component.

Table 11. FTIR Results of Ethyl acetate root extract

\begin{tabular}{ll}
\hline Wave band $\left(\mathbf{c m}^{-1}\right)$ & Description \\
\hline 3423.76 & O-H Stretch for carboxylic acid \\
1642.44 & C=O Stretch for esters, acids \\
443.64 & C-H deformation bonds for methyl groups \\
\hline
\end{tabular}


Table 12. UV-VISIBLE Result of Ethyl acetate root extract

\begin{tabular}{lll}
\hline$\lambda \max (\mathbf{n m})$ & Chromophore & Description \\
\hline 788.00 & $\mathrm{O}-\mathrm{C}=\mathrm{O}$ & $\left(\mathrm{n} \longrightarrow \pi^{*}\right)$ attached to \\
769.00 & $\mathrm{O}-\mathrm{C}=\mathrm{O}$ & alkane bonds. \\
747.40 & $\mathrm{O}-\mathrm{C}=\mathrm{O}$ & “ \\
663.80 & $\mathrm{O}-\mathrm{C}=\mathrm{O}$ & “ \\
608.80 & $\mathrm{O}-\mathrm{C}=\mathrm{O}$ & “ \\
\hline
\end{tabular}

Table 13. Summary of the $H^{l}$ and $C^{13}$ NMR Results of Ethyl acetate root extract

\begin{tabular}{lllll}
\hline $\begin{array}{l}\mathbf{H}^{\mathbf{1}} \boldsymbol{\delta}(\mathbf{p p m}) \boldsymbol{\&} \\
\text { Multiplicity }\end{array}$ & $\begin{array}{l}\text { Coupling } \\
\text { Constant } \\
(\mathbf{M H z})\end{array}$ & $\begin{array}{l}\text { Types of } \\
\text { Proton }\end{array}$ & $\begin{array}{l}\mathbf{C}^{\mathbf{1 3}} \boldsymbol{\delta} \\
(\mathbf{p p m})\end{array}$ & $\begin{array}{l}\text { Types of } \\
\text { Carbon }\end{array}$ \\
\hline $0.85(\mathrm{~d})$ & 6.13 & $\mathrm{CH}_{3}$ & $\mathrm{C}-\mathrm{O}$ & 77.677 \\
$1.1(\mathrm{t})$ & 50.57 & $\mathrm{CH}_{2}$ & $\mathrm{C}-\mathrm{O}$ & 77.047 \\
$2.3(\mathrm{~d})$ & 20.49 & $\mathrm{CH}_{2} \mathrm{OCH}_{2}$ & $\mathrm{CH}_{2}$ & 76.403 \\
$3.8(\mathrm{t})$ & 22.81 & $\mathrm{RCO}_{2} \mathrm{CH}_{2}$ & $\mathrm{CH}_{2}$ & 58.261 \\
& & & $\mathrm{CH}_{2}$ & 29.664 \\
& & & $\mathrm{CH}_{3}$ & 18.287 \\
\hline
\end{tabular}

The combination of the FTIR, UV-VIS, $\mathrm{H}^{1}-\mathrm{NMR}, \mathrm{C}^{13}$ NMR results with major fragments in the GCMS gave rise to the proposed structure for the compound of Ethyl acetate extract (fig 2.0)

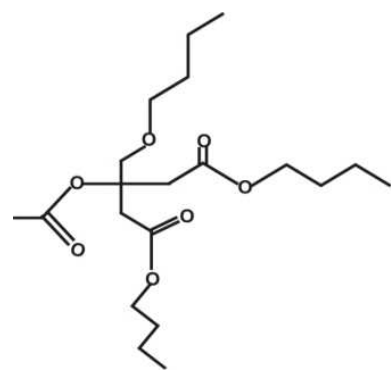

Fig 2.0. 1,2,3-Propanetricarboxylic acid, 2-(acetyloxy)-tributyl ester $\left(\mathrm{C}_{20} \mathrm{H}_{38} \mathrm{O}_{8}\right)$

1,2,3-Propanetricarboxylic acid, 2-(acetyloxy)-tributyl ester found in this extract was a non-poisonous tasteless plasticizer for vinyl resins, rubber and food packaging as well as for making paints, adhesives and coatings. It had no medicinal value and this was confirmed from the results of the antimicrobial screening where the extracts showed no activity on the selected test organisms (Table 5). This indicated that the compound had no contribution to the anti-microbial action of the plant.

\section{Conclusion}

The chloroform root extracts of the plant Ficus exasparata has shown to be a potent medicinal plant for antimicrobial/pharmaceutical applications/treatment of diseases caused by the selected test organisms such as inflammatory diseases, boil, internal abscess etc given its values for the MIC, MBC and MFC. The chloroform isolate (Coumarin-3-carboxamide, 8-allyl-N-(3nitrophenyl)) from this plant part could serve as precursor for drug production while the other 1,2,3Propanetricarboxylic acid, 2-(acetyloxy)-tributyl ester has been shown to be of no medicinal value.

\section{Recommendations}

It is recommended that the roots of this plant should be further purified to reduce the heavy metal content to permissible level. Also, the toxicity and dosage of the plant part should be fully determined through animal inoculation tests.

The active isolates should be formulated into drugs to help in the prevention, treatment and control of susceptible diseases.

\section{References}

[1] Dalziel,J.M., (1961). The Useful Plants of West Tropical Africa, the Crown Agents, London, p.308.

[2] Sofowara, E.A., (1983). Medicinal Plants and Traditional Medicine in Africa, 2nd edn. John Wiley, Winchester, p.10

[3] Edeoga, H.O., Okwu, D.E and Mbaebie O., (2005). Nutritional Values of some known conventional leafy vegetables of Nigeria, African Journal of Biotechnol, 4(7), 685-688.

[4] Filogona, J., Dunah, C.S., and Wakshama, P.S., (2005). An Invitro study of the Antimicrobial Activity of the root extract of calotropis procena and moringa oleifera, Ife Journal of Science, 7(1), 43-44.

[5] Buniyam, A.A., Eric, K.I.Q, Fabian, C.A., (2007). Pharmacognosy and Hypotensive Evaluation of Ficus exasparata Vahl (moraceae) Leave., Acta Polaniae Pharmaceutica-Drug Research, 64(6), 543-546.

[6] Sonibare, M.A., Soladoye, M.O., Esan, O.O., and Sonibare, O.O., (2009). Phytochemical and Antimicrobial Studies of four Species of cola schott and Endl. (sterculiaceae). Afr J Trad CAM., 6 (4), 518-525.

[7] Harbone, J.B., (1998). Phytochemical Methods- A guide to Modern Techniques of plant Analysis, 3rd edn., Chapman and Hall, London, pp.36-89.

[8] Adodo, A., (1998). Nature Power (Revised Edition), Don Bosco Publishers, Akure, Nigeria, p.41.

[9] Adeniyi, B.A.,Groves, M.J., and Gangadharam, P.R.J., (2004). Invitro antimycobacterial activities of three species of cola plant extracts, (sterculiaceae). Phytotherap Res., $18(5), 414-418$.

[10] Idu, M., (2010). Documentationon Medicinal Plants sold in markets in Abeokuta, Nigeria, Tropical Journal of Pharmaceutical Research, 9 (2), 110-118. 

(Anwirinwa)

[11] Reid, K.A., Jager,A.K., Light,M.E., Mulholland, D.A., and Staden, J.V., (2005). Phytochemical and Pharmacological screening of Sterculiacea Species and Isolation of antibacterial compounds, J. Ethnopharmacol, 97(2), 285-291.

[12] Cunha, B.A., (2009). Antibiotic Essentials, $8^{\text {th }}$ edn., Jones and Barlett Learning Publishers, United States, p.180.

[13] Alinnor, I.J., (2007). Preliminary Phytochemical and antibacterial activity screening of seeds of Garcinia Cola, Journal Chemical Society Of Nigeria, 32(2), 41-47.
[14] Penecilla, G.L., Magno, C.P.,(2011). Antibacterial activity of extracts of twelve common medicinal plants from phillipines. J.med.plants research, 5(16), 3975-3981.

[15] Murray, R.D.H ,Mendez, J, Brown, S.A., (1982). In the National Coumarins: Occurence, Chemistry and Biochemistry. John Wiley and Sons: New York, P.227

[16] Kessler C.M., Chest (1991), 99, 97S-112S. (b) O'kennedy R., Thrones, R.D., Eds (1997) Coumarins: Biology, Applications and Mode of Action; Wiley; Chichester, U.K. 